Makale türü / Article type: Araştırma / Research

\title{
Bölgesel Kalkınmada Yayla Turizmi: Rize İli Örneği
}

\section{Regional Development Plateau Tourism: Rize Province Example}

\author{
Yrd. Doç. Dr. Nilgün BİLİCI \\ Atatürk Üniversitesi Turizm Fakültesi, nbilici@atauni.edu.tr
}

Arş. Gör. Zennübe IŞIK

Atatürk Üniversitesi Turizm Fakültesi, zennube.yalcin@atauni.edu.tr

\section{Özet}

Dünyadaki değişime paralel yaşam standartlarının yükselmesiyle, Türkiye'de eko turizm, kültür turizmi, kongre turizmi, av turizmi, spor turizmi, yayla turizmi ve sağlık turizmi gibi farklı turizm tipleri oluşmuştur. Türkiye, doğal ve kültürel değerleri ile turizm yönünden çeşitlilik gösteren bir potansiyele sahiptir. Dünyada olduğu gibi Türkiye'de de eko turizme yönelik turizm talebi artmaktadır. Kırsal alanlar, insanların negatif etki yaratan kent ortamından uzaklaşmasını sağladığ için bu bölgeler önem kazanmakta ve dünyada bu tür yerlerin sahip olduğu fiziki güzellikler ve kültürel değerler ilgi görmektedir. Dolayısıyla birçok ülkede kırsal niteliğe sahip, tahrip olmamış doğa ve kültürel bölgelerin büyük bir bölümünün varlığını sürdürüyor olması bölgesel kalkınma açısından da çekim unsuru oluşturmaktadır. Konu ile ilgili yapılan araştırmalar, gelecek yıllarda turizm anlayışının doğa ile bütünleşen, çevreye karşı bilinçli, yaşam tarzlarını ve kültürleri birlikte tutmaya imkân veren turizm ürünlerine yönelik olacağına da dikkat çekmektedir. Bu araştırmada Rize ilinin sahip olduğu yayla turizminin potansiyel kaynaklarına olan farkındalığın sağlanması ve yayla turizminin bölgesel kalkınmaya katkısı ele alınacaktır.

Anahtar Kelimeler: Bölgesel Kalkınma, Turizm, Bölgesel Ekonomi, Rize.

JEL Sinıflandırması: Z3, Z30, Z32

\begin{abstract}
The change in parallel with the rise of living standards in Turkey, eco-tourism, cultural tourism, Congress tourism, hunting, sports tourism, Plateau tourism and health tourism is composed of different types of tourism, such as. Turkey, in terms of tourism with natural and cultural values of the diverse potential. Eco tourism in Turkey as in
\end{abstract}


the world tourism trend is increasing. The negative impact of people in rural areas, the City provides to step away from these areas are important, and this kind of place in the world of physical beauty and cultural values, interest. Therefore, in many countries, unspoiled nature and rural qualification, with a large portion of the cultural district's presence continues to be in terms of regional development, constitute an element of shooting. Topics related to the research, the understanding of nature tourism in the coming years, with integrated, environmentally conscious, lifestyles and cultures together will prove to be for tourism product which is to keep attention. In this study, the potential of Rize province-owned Highland tourism resources is providing awareness and plateau tourism's contribution to the regional development will be addressed.

Keywords: Regional Development, Tourism, Regional Economy.

JEL Classification: Z3, Z30, Z32

\section{GÍRIŞ}

Türkiye'de deniz, güneş, kum üçlüsünden sonra tüketiciler artık farklı turizm çeşitlerine yönelmektedir. Bozulmamış tabii yapısı, geleneksel yaşam kültürü ve sakin bir ortam sunmaları neticesinde ülkemizin yaylaları gittikçe turistik çekim merkezine dönüşmektedir. Bilhassa sıcak yaz aylarında çok yüksek olmayan dağlık alanların 1lıman iklimi, alışılagelmiş yaylacılık kültürüne rekreasyon işlevi de kazandırmıştır (Doğanay, 2001). Kültür ve Turizm Bakanlığı'nın alternatif turizm kapsamında başlatmış olduğu turizm çeşitlendirme çabalarının başında yayla turizmi gelmektedir. Bakanlık bu kapsamda çok sayıda alanı Yayla Turizmi alanı ilan etmiştir. Ayrıca yaylaların turistik aktivitelerde kullanılabilirliğini sağlayacak farklı projeler geliştirmeye başlamıştır. Yaylalarda yeni trend turizm çeşidine yönelik gerekli olan alt yapı olanaklarının geliştirilmesi için yeni yatırımlar yapmıştır. Bakanlık tarafından yapılan çalışmalar neticesinde, yaylalara olan talep, ağırlıklı olarak yerli turist tarafından gösterilmiştir. Günümüzde de yayla turizmi aktivitelerine dış turizm talebi de yönelmeye başlamıştır.

Turizm sektöründe sürdürülebilirlik oldukça önemli bir kavramdır. $\mathrm{Bu}$ kavramın sağlanabilmesi için toplumların sahip olduğu kültürleri ve folklorik unsurları, ülke veya bölgelerin çevre ve iklim yapısı gibi etkenlerin korunması ve geliştirilerek gelecek nesillere mümkün mertebe bozulmamış bir şekilde 
aktarılmasının sağlanması gerekmektedir. Bu sayede korunan ve geliştirilen kaynaklar, gelecek kuşakların tam anlamıyla hizmetine sunulabilecektir. Dolayısıyla turizm kısa vadeli değil uzun vadeli düşünmeyi ve bu kapsamdaki çalışmaları gerektirmektedir. Sürdürülebilir kalkınma, ekonomik kalkınmaya süreklilik kazandıracak bir şeklide insan sağlığını ve doğal dengeyi koruyarak doğal kaynakların rasyonel yönetimini sağlamak ve gelecek nesillere yaşayabilecekleri tahrip edilmemiş fiziki ve sosyal çevre bırakmak yaklaşımıdır. $\mathrm{Bu}$ tür bir yaklaşım kalkınma yolunun her aşamasında ekonomik, sosyal ve çevre politikalarının birlikte ele alınıp, entegre bir şekilde uygulanmasını zorunlu kılmaktadır. (Godfrey, 1996).

Gelişmiş ya da gelişmekte olan ülkelerin çoğunun bölgeleri arasında mevcut olan kalkınma ve gelişme farklılıkları, bu ülkeleri bölgeleri arasında var olan kalkınma farklılıklarını giderecek ya da en aza indirecek stratejileri uygulamaya ve birtakım önlemleri almaya zorlamaktadır. Dolayısıyla yönetimler, bölgeleri arasındaki potansiyelleri çok iyi analiz ederek bu potansiyellere uygulanabilir çeşitli stratejiler üretmeye yönelmektedir. $\mathrm{Bu}$ doğrultuda ekonomik olarak gelişmiş ülkelerin birçoğunun milli gelirinde azımsanamayacak bir yer tutan turizm sektörünün potansiyeli olan bölgelere yönlendirilmesi ve bu bölgelerin turizm için daha çekici hale getirilmesi ile gelişememiş bölgelerin de kalkınmaları için yararlı gelişmeler sağlayacaktır. Bu bağlamda yapılan bu çalışmada bölgesel kalkınma çerçevesinde, turizmin Rize iline, Rize ilinin de bölgesel kalkınmaya katkıları açıklanmıştır.

\section{BÖLGESEL KALKINMA, TURIZM VE YAYLA TURİMI KAVRAMI}

Ülkeler sosyo-ekonomik şartlar, jeolojik özellikler, ulaşım kolaylığı, doğal kaynaklar, yapılan yatırımlar gibi farklı niteliklere ve kaynaklara sahip olma özelliklerinden dolayı farklı gelişmişlik düzeylerine sahiptirler, kendi içinde farklı coğrafi bölgelere ve bölümlere ayrılmaktadırlar. Dolayısıyla ülkelerin farklı bölge ve bölümlerine yapılan yatırımlar ve ihtiyaçlar da farklılık göstermektedir. Bazı bölgeler oldukça gelişmişlik gösterirken bazı bölgeler ise hem doğal nedenlerden dolayı hem de yapılan yatırımların eksikliği nedeniyle az gelişmiş veya gelişememiş olabilmektedir. Doğal olarak bölgeler arasında gelişme farklılıkları görülmektedir. Bu farklılıkların 
ortadan kaldırılabilmesi için gelişememiş bölgeler için bölgesel kalkınmayı sağlayacak girişimler de bulunulmalıdır. Bölgesel gelişmişlik farklılıkları günümüzde ekonomilerin en belirgin özelliklerinden biridir. Bölgesel kalkınma, endüstriyel faaliyetlerin belirli bölgelerde kümelenmesi sonucu oluşan dengesizliği yok etmek amacıyla, gelişmemiş ya da gelişemeyen bölgelerin sanayileşmesini ve ekonomik kalkınmasını hedefleyerek ülke içinde eşit gelir dağılımının sağlanmasını ifade etmektedir (Ildırar, 2004).

Bölgesel kalkınma ile bölgelerarası gelir dağılımının iyileştirilmesi ve tarımsal gelişme, sanayi, kentsel ve kırsal altyapı, haberleşme, eğitim, sağlık, kültür, turizm ve diğer sosyal hizmetler gibi sosyo ekonomik sektörlerin geliştirilmesine yönelik yatırım ve etkinlikleri de içermektedir. Bölgesel kalkınmanın gerçekleşebilmesi için her bölgeye uygun farklı bölgesel politika hedefleri oluşturulmalıdır. Bölgesel kalkınma politikalarının hedefleri, ekonomik kaynakların adil kullanımını sağlamak, devlet kaynaklarının en uygun şekilde kullanımını sağlayarak bölgesel gelişmedeki fark ve dengesizlikleri en aza indirmektir. Bölgelerarası farklılık sadece Türkiye'ye ait bir gerçek değildir. Gelişmekte olan ülkeler kadar gelişmiş ülkelerde de bu sorun yaşanmaktadır. Örneğin, farklı kültürler, diller, tarihler ve geleneklerden oluşan Avrupa Birliği içinde, hem üye ülkeler arasında hem de değişik bölgeler arasında farklılıklar vardır. Bu durum AB'ye üye ülkelerin bölgeleri arasında değişik düzeylerde yaşam standartları yaratmıştır. Avrupa Birliği'nin en zengin 10 bölgesi, en yoksul 10 bölgeye göre 35 kat daha büyüktür; en kötü durumdaki 10 bölgede işsizlik, en iyi durumdaki on bölgeye oranla yedi kat daha yüksektir (İzgi, 2007).

Gelişmekte olan ülkelerde bölgesel gelişmişlik farklılıkları konusunda dikkati çeken önemli konulardan birisi de ülkelerdeki bazı bölgelerin tüm desteklere karşın gerilemeye devam etmesi iken, hiçbir ilave destek almayan bazı bölgelerin ise beklenmedik bir şekilde aradaki farklılıkları kapatmaya başlamalarıdır. Bölgesel kalkınmayı, bölgedeki kaynakların etkin kullanıma sunulması, girişim faaliyetlerinin artırılmasının desteklenmesi, bölgenin gelir ve istihdam seviyelerinin artırılarak genel hayat standartlarının iyileştirilmesi olarak ifade etmek mümkündür (Durgun,2006). Bölgelerin sahip olduğu potansiyel bazı kaynaklar kullanılarak gelişmelerine katkıda bulunulabilecek faktörlerden biride turizmle ilgili potansiyellerdir. Çalışmamıza da kaynak 
teşkil eden doğal kaynaklardan olan yaylalarımızın turizme kazandırılarak bölgesel kalkınma sağlanması amaçlanmaktadır. Buna bağlı olarak hayat standartlarının gelişmesi ile insanların turizme olan ilgilerinin de artış göstereceği düşünülmektedir.

İnsanlar, sürekli yaşadıkları yerlerden geçici sürelerle ayrılarak başka ülke veya bölgelere gitmekte ve buralarda gezip-görme, dinlenme, eğlenme, öğrenme gibi psikolojik ve sosyo-kültürel ihtiyaçlarını karşılamaktadırlar. Ekonomik olarak da büyük katkılar sağlayan ve turizm olarak isimlendirilen olay, çağımızın temel ekonomik bir fonksiyonunun niteliğini oluşturmaktadır (Uçkun, 2004).

Turizm, geçmişten günümüze kadar gelişmiş ve gelişmekte olan ülkeler tarafından oldukça ilgi gören bir sektör olma niteliği taşımaktadır. Bunun en önemli sebebi ise, dünya çapında en hızlı gelişim gösteren sektörlerden biri olmasıdır. Bu durum, turizm sektörünün ülke ekonomilerine katkılarını ön plana çıkarmış ve Dünya turizm Örgütünün 2020 y1lında dünya turizm gelirinin 2 trilyon dolar olacağına ilişkin öngörüsünün de etkisiyle her ülkenin kendi turizm arz potansiyeli oranında bu pastadan pay alma veya aldıkları payı büyütme mücadelesine girişmelerine sebep olmuştur. Turizm sektörünü geliştirerek ülkelerin gelişmişlik düzeylerine göre erişmek istediği hedef değişiklik gösterebilmektedir. Gelişmiş ülkeler turizm sektörünün gelir etkisinden faydalanmaya çalışırken gelişmekte olan ya da az gelişmiş ülkeler ise, turizm sektörünün döviz sağlayıcı ve yeni iş imkânları yaratabilme gücünden faydalanmak istemektedirler (Yıld1z, 2011). Ülke ekonomilerinde ve toplumsal kalkınmada stratejik bir konumda olan turizm, dünya ekonomisi için vazgeçilmez bir sektördür. Bölgelerarası kalkınma seviyelerini dengelemek, kaynakları etkin kullanmak, turist sayısını ve turizm gelirlerini artırmak maksadıyla turizm etkinlikleri günden güne daha çok önem kazanmaktadır. $\mathrm{Bu}$ kazanımlarla turizm sektörünün makro anlamda ülke ekonomisine mikro anlamda ise bölge ekonomisine sağladığı katma değerleri ön plana çıkmaya başlamakta ve alternatif turizm arayışları hız kazanmaktadır (Uğuz, 2011). Bu bağlamda Yayla turizmi, alternatif turizm arayışları içinde oldukça büyük önem taşımaktadır.

Geleneksel kullanım şekliyle yaylalar, hayvanların yeme ihtiyaçlarının karşılandığ 1 , kış mevsiminde hayvanların tüketmeleri için otların toplandığ 1 , 
yaz mevsiminde daha serin şartlarda yaşamak için yılın belli dönemlerinde kullanılan mekânlar şeklinde ifade edilmektedir. Ayrıca yaz aylarında yaşanan en sıcak günlerde sıcaktan bunalan insanlar tarafindan geçici bir süre ile çıkılan, kış aylarında olumsuz hava koşulları sebebiyle kullanılmayan, hayvancılık faaliyetleri için oldukça elverişli, dağların yüksek kesimlerinde bulunan düzlükler olarak ta tanımlanmaktadır. Mekânsal olarak incelendiğinde yaylalar bahar aylarında başlayan mevsimlik ya da dönemlik otlaklardır (Ögel, 2000). Yaylalar çoğunlukla köy veya kasaba gibi topluluklara ayrılmıştır. Coğrafi bakımdan dağ sıraları üstünde yer alan büyük düzlüklere yayla denilmektedir. Yaylalar şekil açısından yüksek dağların yamaçlarında yer alan, akarsular tarafindan vadilerle parçalanmış düzlüklerdir (Daşcı ve Çomakl1, 2006). Yaylalar, kent yaşamının bunalttı̆̆ insanlara el değmemiş bakir tabiatın kirlenmemiş, tertemiz havasını, engin dağların billur gibi saf ve soğuk sularını sunmaktadır. Bu mekânlar 1990'lı yıllardan sonra turizme açılmıştır ve alışılmış yaşam biçimine ek olarak turistik beklentilere de cevap verecek şekilde düzenlemeler yapılmıştır. Dolayısıyla yaylalara yönelik talep artmıştır (Atasoy ve Bıyık,2005). Yaylalar gelecekte kış turizminin daha çok ilgi alanı olacaktır. Böylece yaylaların bütün yıl boyunca turizmde kullanımı mümkün olacaktır (Doğaner, 2001). Türkiye'de yaylacılık, coğrafi bölgelere hatta illerine göre özgün coğrafik özellikleri, yayla adına yazılıp söylenen şarkı ve türküleri, mimarisi, terminolojisi, yaban hayvanları, yiyecekleri, şenlikleri, bitki örtüsü, inanışları, hastalıkları, kullanılan aracı ve gereci olan ayrı bir kültürdür. Bu kaynakların ve kültürün etkin kullanımı ile hem mevcut potansiyel ortaya konularak fonksiyonel hale getirilecek hem de farkındalık yaratılarak bu bölgelerin yapısı da korunmaya çalışılacaktır. Günümüzde yayla ve yaylacılık, ekonomik faaliyetler bakımından çeşitlilik göstermektedir. Ülkemizin farklı bölgelerindeki yaylalarda hayvancılık faaliyetlerinin yanı sıra çok çeşitli tarım ürünleri de yetiştirilmektedir. Özellikle son zamanlarda Karadeniz ve Akdeniz Bölgelerinde yer alan yaylalarda tarım ve hayvancılık faaliyetleri hızla değişmektedir. Bu faaliyetlerin yerini artık turistik faaliyetler devralmaktadır (Ertürk, 1995). Buna bağlı olarak, yaylalarda yapısal olarak görülen değişimler başında ise yaylaların alt yapı imkânlarına önem verilmesi gelmektedir. Yaylalara giden yolların düzenlenmesi, yaylalara elektrik 
ulaştırılması hatta yaylaların bazılarına telefon hatlarının bağlanması yaylaların yaygın kullanılış özelliğini büyük ölçüde değiştirmiştir. Özellikle son zamanlarda kent yaşamının sıcağından ve gürültüsünden kaçarak yaylaların serin, tertemiz havasından, buz gibi sularından ve sakin, gürültüden uzak ortamından faydalanmak isteyen insanlar, yaylaları birer sayfiye alanına dönüştürmektedir. $\mathrm{Bu}$ noktada şehir hayatının konforuna ulaşılabilecek kalitede yayla turizmi adından söz ettirmektedir.

Yayla turizmi; klasikleşen deniz-güneş-kum üçlüsüne dayanan kitle turizminden farklı özellikleri olan, daha spesifik motiflerle harekete geçirilen alternatif bir turizm ürünüdür. İnsanların bulundukları yerlerden uzaklaşarak yazın aşırı sıcak aylarında yaylalara çıkması ve orada konaklama yaparak ihtiyaçlarının tümünü karşılayabilmeleri yayla turizmi hareketini yaratmaktadır. (İTO, 1997).

Doğal ortamlarda bireylere stresli alanlardan uzaklaşarak dinlenme ve rahatlama olanağı sunan yayla turizmine yönelik özellikleri aşağıdaki gibi siralamak mümkündür (Albayrak, 2013):

- Yayla turizmi, özellikle aktif olarak çalışma hayatı olan kişilerin iş ortamındaki stres, işletmeler tarafindan konulan davranış kuralları ve kalabalıktan uzaklaşma isteğine bağlı olarak ortaya çıkan, insanların doğa ile iç içe olma, farklı iklim koşullarında yaşama ve doğal olarak beslenme ihtiyacını karşılamalarına olanak veren bir turizm türüdür.

- Yayla turizmine ülkemizde genel olarak aile ve arkadaş grubu olarak seyahat eden turistler katılmaktadır. Bireysel olarak yayla turizmine katılım pek görülmemektedir.

- Yayla turizmindeki katılımcıların konaklama süreleri kıyı turizmine katılan turistlerin konaklama sürelerinden daha uzun sürmektedir.

- Yayla turizmi katılan turistlerin detaylı bir seyahat planları mevcut değildir. Bunun yerine uzun bir zamana yayılmış pasif aktiviteler ile ilgilenmektedirler.

- Yayla turizmi, kıyı turizminin aksine deniz seviyesinden yüksekte olan bölgelerde yapılan bir turizm türüdür.

- Genellikle kırsal turizmin gerçekleştirildiği bölgelerde bölgenin özelliklerine uygun geleneksel kırsal yaşam ortamının mimari özelliklerini yansıtan konaklama gerçekleştirilmektedir. 
- Yayla turizmine her yaş grubundan ve farklı eğitim düzeyinde olan insanlar katılmaktadır. Genellikle düşük ve orta seviyeli gelire sahip insanlar tarafından tercih edilmektedir. En büyük amaçlarından birisi doğayla iç içe olmaktır. Türkiye'de bulunan yayla alanlarının çoğunun turizm merkezi olarak ilan edilebilmesi için bazı kriterlere uyulması gerekmektedir. $\mathrm{Bu}$ nitelikler şöyle sıralanmaktadır (Hacıoğlu ve Avcıkurt,2011);

- Doğal değerlere yönelik potansiyelin zengin olması,

- Sivil mimari karakterinin olmasi,

- Kent merkezine ulaşımın kolay sağlanır olması,

- Yöre halkının sosyal yapısının turizme yatkın olması,

- Aktivitelerin ekonomik olarak sürdürülebilmesi,

- Diğer turizm çeşitleri ile entegrasyonunun sağlanabilir olması, şartlarını taşıyan yaylalar turizm merkezi olma kriterlerine uymaktadır.

Türkiye coğrafi yapısı gereği irili ufaklı pek çok yaylaya sahiptir. Ülkemizde bulunan yaylaların tam sayısı ifade edilememekle birlikte en fazla yayla Karadeniz Bölgesinde bulunmaktadır. Aşağıdaki tabloda Karadeniz bölgesinde yer alan yaylalar gösterilmiştir:

Tablo 1. Karadeniz Bölgesi Yaylaları

\begin{tabular}{|c|c|c|c|}
\hline \multirow{7}{*}{ 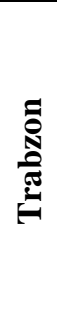 } & Maçka-Şolma Yaylası & & Kümbet Yaylası \\
\hline & Kiraz Yaylası & \multirow{6}{*}{ 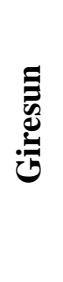 } & Hanalanı Yaylası \\
\hline & Maçka-Mavura Yaylası & & Tamdere Yaylası \\
\hline & Düzköy Yaylası & & Bektaş Yaylası \\
\hline & Lapazan Yaylası & & Yavuz Kemal Beldesi Yaylası \\
\hline & Sera Gölü Çevresi & & Dokuzköy ve Çakrak Yaylaları \\
\hline & Arakl1-PazarcikTurizm & & Tamzara, Paşakonağı ve Anastos \\
\hline \multirow{6}{*}{ 沗 } & Yusufeli-Kackar Turizm Merk. & \multirow{6}{*}{ 离 } & Kop Dağı Turizm Merkezi \\
\hline & Sahara ve Arsiyan Yaylaları & & Sultan Murat Yaylası \\
\hline & Kafkasör Turizm Merkezi & & Aydıntepe ve Akbulut Yaylaları \\
\hline & Şavşat-Karagöl Yaylası & & Otlukbeli ve Yoncalı Yaylaları \\
\hline & Ardanuç Babilan Yaylası & & Dumlu ve Göloba Yaylaları \\
\hline & Borçka-Karagöl Yaylası & & \\
\hline
\end{tabular}




\begin{tabular}{|c|c|c|c|}
\hline \multirow{6}{*}{ 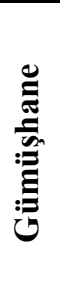 } & \multicolumn{2}{|l|}{ Zigana Turizm Merkezi } & Çamlıhemşin-Ayder Kaplıca \\
\hline & \multicolumn{2}{|l|}{ Altıntaşlar Yaylası } & Turizm Merkezi \\
\hline & Çatmaobası Yaylası & & Ayder Yaylası \\
\hline & Sazalanı yaylası & בิ & İkizdere-Anzer Yayla Turizm \\
\hline & \multicolumn{2}{|l|}{ Kadırga Yaylası } & Merkezi \\
\hline & \multicolumn{2}{|l|}{ Tonya-Erikbeli Turizm Merk. } & \\
\hline \multirow{4}{*}{ 章 } & \multicolumn{2}{|l|}{ Gürfındık-Bozarmut Yaylaları } & Perşembe- Keyfalan Yaylaları \\
\hline & \multirow{3}{*}{$\begin{array}{l}\text { Türkeli-Kurugöl Yaylaları } \\
\text { Ayancık-Akgöl Yaylaları } \\
\text { Durağan-Bozluk Yaylaları }\end{array}$} & \multirow{3}{*}{ 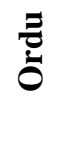 } & Çambaşı ve Arhın Yaylaları \\
\hline & & & Yeşilce ve Topçam Yaylaları \\
\hline & & & \\
\hline \multirow{3}{*}{ 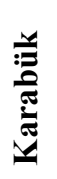 } & \multirow{3}{*}{$\begin{array}{l}\text { Sorkun ve Ula Yaylaları } \\
\text { Sarıçiçek Yaylası } \\
\text { Boduroğlu ve Dede Yaylaları }\end{array}$} & \multirow{3}{*}{ 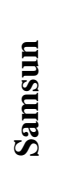 } & Akdağ Yaylası Kayak Merkezi \\
\hline & & & Kocadağ ve Ladik Yaylaları \\
\hline & & & \\
\hline \multirow{4}{*}{ 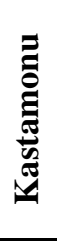 } & Munay, $\quad$ Findıklı, $\quad$ Kirazlı & \multirow{4}{*}{ 方 } & Karg1 ve Abdullah Yaylaları \\
\hline & & & Bayat Kunduzlu ve Kuşçaçimer \\
\hline & $\begin{array}{c}\text { Oluklu, Suğla, } \\
\text { Yaylaları }\end{array}$ & & $\begin{array}{l}\text { Yaylaları } \\
\text { İskilip ve Elmabeli Yaylaları }\end{array}$ \\
\hline & $\begin{array}{c}\text { Sekiler, Kösem ve Ayrancı } \\
\text { Yaylaları }\end{array}$ & & Osmancık Yaylaları \\
\hline$\stackrel{\mathscr{N}}{:}$ & Topuk ve Karadüz Yaylaları & 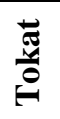 & $\begin{array}{c}\text { Topçam, Selemen ve Batmantaş } \\
\text { Yaylaları }\end{array}$ \\
\hline \multirow{3}{*}{$\stackrel{\Xi}{\circ}$} & Aladağ, $\quad$ Kızık, & \multirow{3}{*}{ 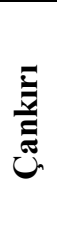 } & Yapraklı Yaylası \\
\hline & $\begin{array}{c}\text { Yaylaları } \\
\text { Seben, Kıbriscık, Mudurnu } \\
\text { Yaylaları }\end{array}$ & & Kırkpınar ve Bozan Yaylaları \\
\hline & $\begin{array}{c}\text { Burnuk, Civcivler, } \\
\text { Yaylaları }\end{array}$ & & \\
\hline
\end{tabular}

Kaynak: Hacığlu ve Avcıkurt (2011:148).

\section{TURIZMIN BÖLGESEL KALKINMADAKİ YERİ VE ÖNEMİ}

Turizmin esas faktörleri arasında ülkelerin kültürel değerleri, geçmişten gelerek geleceğine 1şık tutan tarihi, klimatik özellikleri, sahip olduğu doğası yer almaktadır. $\mathrm{Bu}$ faktörler, turizm olayının olağan neticesi sayesinde ekonomik değeri olan mal niteliği kazanmaktadır. Tarım ve sanayi bakımından gelişmemiş ya da gelişemeyen ancak turizm potansiyeli açısından zengin olan bölgeler, etkin ve planlı bir turizm stratejisiyle bölgesel olarak kalkınma sağlayabilmektedir. Akılcı bir turizm kalkınması, turizm adına 
yapılan yatırımların ülkenin bütün bölgelerine eşit bir şekilde dağılımını değil de turizm potansiyeli olarak daha ön plana çıkmış bölgelere yoğunlaşmasını gerektirebilmektedir. $\mathrm{Bu}$ yoğunlaşma ülke piyasasının ekonomik faaliyetlerinin işleyişine bağlı olarak kendiliğinden meydana gelebileceği gibi devlet tarafından sunulan teşvikler neticesinde de ortaya çıkabilmektedir (Bilginoğlu, 1995).

Ekonomik olarak kalkınma doğrultusunda değerlendirildiğinde turizmin, kamu gelirlerini artırdığı görülmektedir. Herhangi bir bölgede turizmin gelişme göstermesiyle beraber bölgedeki arazi fiyatları da yükselmektedir. Dolayısıyla arsa ve arazi alım satım durumları da artmaktadır. Böylece devletin vergi gelirlerinde artış gözlenmektedir. Devlet hazinesine giren vergi gelirleri kapsamında emlak alım-satım vergisi, işletmelerin yapmış olduğu her türlü alım satımdaki katma değer vergisi, işletmelerde çalışan personelin maaşlarındaki gelir vergisi gibi vergi çeşitleri bulunmaktadır. Hatta bu vergilerden emlak vergisi ve çevre temizlik vergisi gibi vergi çeşitleri direkt olarak bölgesel niteliklidir. Nitekim sağlanan bu vergi gelirleri bölgesel kalkınmayı sağlamak için devlet tarafından yapılacak olan yatırım ve transfer harcamalarına kaynak oluşturmaktadır (Kılıçlar, 1998).Turizmin diğer sektörlere olan etkisi nedeniyle oluşan katma değerlerinde vergi gelirlerini artırdığ 1 yadsınamaz bir gerçektir.

Turizm, Türkiye'de gelişen bir ekonomi olarak hızla büyüyen sektördür. Birçok farklı alternatifi ile sürekli gelişim göstermektedir. Böylece turizmin ülke ekonomisine de artan katkısı olmaktadır. Dolayısı ile gelişen turizm sektörü beraberinde hem ülke kalkınmasına hem de bulundukları bölgelerin kalkınmasına katkı sağlamaktadır. Alternatif bir ihracat türü olan turizm harcamaları, sağlanan döviz gelirleri yardımıyla ödemeler dengesine olumlu katkı sağlamaktadır. Nitekim turizmin gelişme göstermesiyle beraber bir ülkenin ulusal ekonomisi için oldukça önemli bir gelir kaynağı olmaktadır (Kim, Chen ve Jang, 2006). Turizm sektöründen elde edilen bu gelir, ekonomik büyüme ve kalkınma amacıyla, diğer sektörler için gerekli olan mal ve hizmetlerin ithalatında kullanılmaktadır (McKinnon, 1964). Turizm sektörü özellikle bölgelerarası kalkınma dengesizliğinin giderilmesinde, tarım ve sanayide yeterli kaynak ve gelişme imkânına sahip olmayan ama zengin bir 
turistik arz verilerine sahip bölgelerin, planlı ve etkin bir turizm politikaları uygulamaları sonucunda turistik yönden dengeli bir şekilde kalkınmalarını sağlamaktadır (Braden and Winer, 1980).

Turizm, ülkede yeni istihdam alanları yaratması sayesinde bölgelerarası gelir dağılımında olumlu etki yapmakta ve böylece bölgelerde dengeli kalkınmaya imkân sağlamaktadır (Robert ve Goeldner, 1990). Turizm sektörüne paralel olarak turizmin gelir etkisinin artması, tarım sektöründe üretim kalitesinin artmasına, standardizasyonun sağlanmasına ve kaliteli ürünün gerçek değerini bulmasına katkı sağlamaktadır. Bir bölgedeki turizmin doğaya dayalı olarak ortaya çıkışı büyük kent ve sanayi merkezinde kazanılmış gelirlerin kırsal yörelere aktarılmasını sağlayarak hem ülke düzeyinde hem de uluslararası düzeyde gelirin yeniden dağılımında etkili olmaktadır. Bu süreç bölgelerarası dengesizliği giderici bir rol ifade edeceği gibi sosyal adalet ilkesinin de uygulama alanına aktarılmasını sağlamaktadır (Çetiner,1998). Böylece her nerede yaşanırsa yaşansın insanca yaşamaya olanak verecek şartların tesisi sağlanmış olmaktadır.

Türkiye'de turizm gelirleri ile ortalama harcama arasındaki ilişki bize sektörel ve ekonomik anlamda gelişme hakkında bilgi vermektedir. Bu amaçla verilere bakılarak bir kanıya varmak mümkün olabilecektir. Tablo 2 'de yıllar itibariyle elde edilen turizm gelirleri ve ortalama harcama miktarları gösterilmiştir.

Tablo 2: Yıllar İtibariyle Turizm Gelirleri Ve Ortalama Harcama Miktarları

\begin{tabular}{lcc}
\hline Yillar & Turizm Gelir $\mathbf{( 1 0 0 0} \$)$ & Ortalama Harcama $\mathbf{( \$ )}$ \\
\hline 2003 & 13.854 .866 & 850 \\
2004 & 17076606 & 843 \\
2005 & 20.322 .112 & 842 \\
2006 & 18593951 & 803 \\
2007 & 20942500 & 770 \\
2008 & 25415067 & 820 \\
2009 & 25064482 & 783 \\
2010 & 24930997 & 755 \\
2011 & 28115692 & 778 \\
2012 & 29007003 & 795 \\
2013 & 32310424 & 824 \\
2014 & 34.305 .904 & 828 \\
2015 & 31464777 & 756
\end{tabular}




\begin{tabular}{lcc}
\hline Yıllar & Turizm Gelir (1000 \$) & Ortalama Harcama $\mathbf{( \$ )}$ \\
\hline 2016 & 22107440 & 705 \\
\hline
\end{tabular}

Kaynak: http://www.tursab.org.tr/tr/istatistikler/turist-sayisi-ve-turizm-geliri/2003gelirsayi-ve-ortalama-harcama_68.html

Tablo 2' de görüldüğü üzere turizmden elde edilen gelirler giderek artış göstermektedir. Dolayısıyla ülkemiz ekonomisi turizm gelirleri sayesinde gelişme göstermektedir diyebiliriz. Ortalama harcama miktarlarına baktığımızda ise yıllar itibariyle farklılık göstermekte ancak tutarların birbirine oldukça yakın miktarlarda olduğu görülmektedir.

\section{BULGULAR VE TARTIŞMA}

\subsection{Rize İlinde Yayla Turizminin Bölgesel Kalkınmaya Etkisi}

Türkiye'nin en güzel illerinden birisi olan Rize, Doğu Karadeniz bölümünün kuzey yamaçlarında yer almaktadır. Rize kabul görülen genel bir ifadeyle dağlık ve engebeli topraklara sahiptir. İklim durumu değerlendirildiğinde, Rize ilinde yaz mevsimi serin geçerken kış mevsimi ise 1lımandır. Hemen hemen her mevsim yağış görülmektedir ve yağış mevsimlere dengeli olarak dağılmaktadır. Nitekim yıllık toplam yağış miktarının 2.300 mm'nin üzerinde olmasıyla Türkiye'nin en fazla yağış alan ili unvanına sahiptir. Ülkemizin paha biçilmez güzellikler ile süslenmiş, yeşil ile mavinin en göz alıcı şekliyle birleştiği nadide ilimiz Rize, tarihi ve arkeolojik değerlerine ek olarak doğal ve turistik açıdan da mukayese edilemeyecek kadar zengin bir yapıya sahiptir. İlin güney sınırını oluşturan dağların denize bakan eteklerinde irili ufaklı pek çok yayla bulunmaktadır. $\mathrm{Bu}$ yaylalar daha çok Hemşin, Çamlıhemşin, İkizdere gibi yerleşmelerin çevresinde yoğunluk kazanmaktadır. Dağlarda karların erimesi ile birlikte hayvanlarıyla beraber yaylalara çıkan yöre insanı sıcak yaz aylarını yaylada geçirdikten sonra soğukların başlaması ile sonbahar mevsiminin sonunda tekrar sürekli yaşadıkları yerlere dönmektedirler. Bu yaylalar, el değmemiş doğal güzellikleri, yöreye özgü mimari karakteri ve kendine has yayla yaşantıları ile yerli ve yabancı turistlerin ilgisini çekmektedir. (http://rizesube.ormansu.gov.tr). 
Rize dik yamaçlı vadileri, doruklara ulaşabilir yüksek dağları, buzul gölleri, göz kamaştıran zümrüt yeşili yaylaları, tarihi kemer köprüleri ve kaleleri, coşkun akan dereleri ile çok özel bir turizm destinasyonudur (Bilici, 2014). Kano, kayak gibi hobileri gerçekleştirmeye yönelik uygun ortamları mevcuttur. Kaçkar sıradağlarının eteklerinde Çamlıhemşin ve İkizdere ilçelerinde yoğun bir biçimde yer alan yaylalar iyi korunmuş, özgün mimarili evleriyle bulutların ötesinde bir yaşam sunmaktadır. Bu yaylalardan Ayder, Aşağ1 Yukarı Kavran ve Anzer yaylaları 'Turizm Merkezi'dir'. Bu yaylalar özellikle yaz aylarında yerli ve yabancı turistlerin ziyaret ettikleri yerlerdir. Rize iline genel olarak bakıldığında şehirde konaklayan ve şehri ziyaret eden toplam turist sayısı ve yaylayı ziyaret eden toplam turist sayısındaki artışın beraberinde ilde ve yayla bölgesinde olan konaklama işletmelerinde artışa sebep olmakla birlikte, turizm sektörü ile de bağlantılı olarak birçok sektörde talep artışını da beraberinde getirmektedir.

Şekil 1. Rize ili Haritası

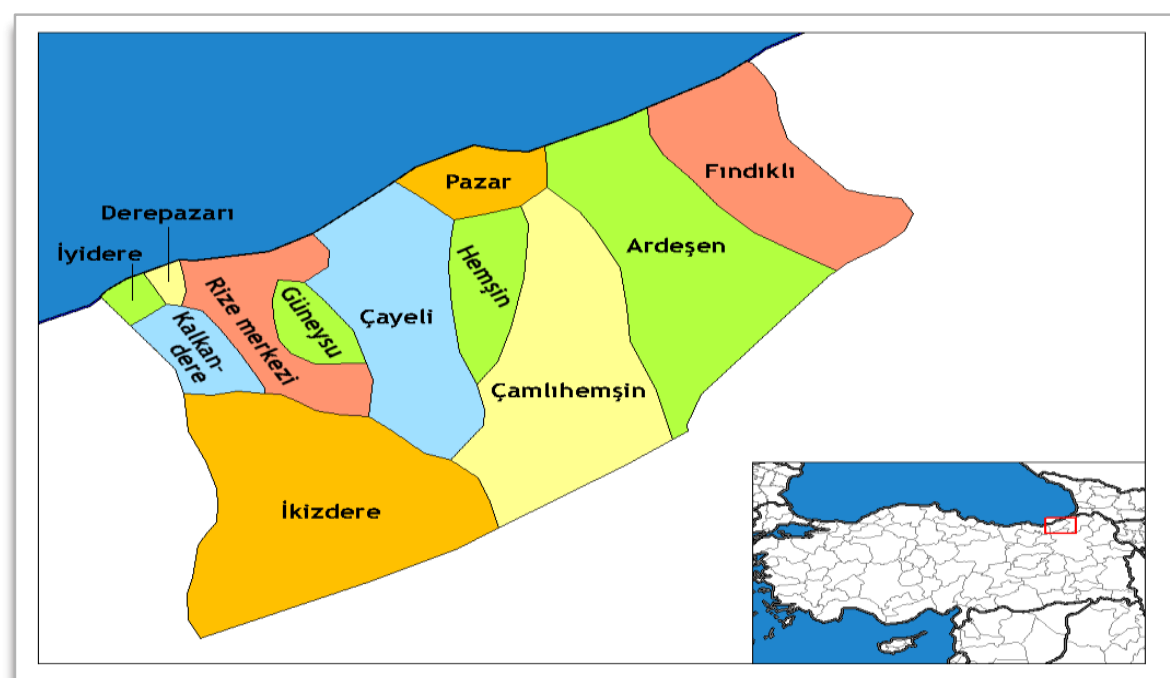

Kaynak: http://tr.wikipedia.org/wiki/Rize (2015).

Rize ilinin coğrafi bölümlere ayrılmış olan haritasında yer alan hemen her yerleșim biriminde bazen bir bazen birden fazla yayla yer almaktadır. $\mathrm{Bu}$ coğrafi bölgelerde ayrıca farklı turistik destinasyonlar bulunmaktadır. $\mathrm{Bu}$ turistik alanlardaki destinasyonlar günden güne insanların ulaşabileceği ve 
yararlanabileceği hale getirilmekte ve turistik hizmet üretimine katılmaları sağlanmaktadır. Bunlardan biri de Rize ilini Doğu Anadolu'ya bağlantısının daha kolay ve her mevsim ulaşılabilir hale getirecek Ovit dağı İkizdere de sonuna yaklaşılan tünel projesidir.

Bütün bunların yanında doğal sit alanları da potansiyel turizm alanlarıdır. Bunlar Kültür ve Turizm Bakanlığınca bir liste halinde ilan edilmiştir. Rize ilinde bulunan arkeolojik ve doğal sit alanları Tablo 2 'de gösterilmektedir.

Tablo 3. Rize İli Arkeolojik ve Doğal Sit Alanları

\begin{tabular}{lll}
\hline Sit Alanı & İlçe & Mevki;Köy Mahalle \\
\hline Doğal Sit Alanı & Mekez & Kırklartepe Köyü, Ayane Tepesi \\
$\begin{array}{l}\text { Arkeolojik Sit } \\
\text { (Zilkale) }\end{array}$ & Çamlıhemşin & Zilkale \\
$\begin{array}{l}\text { Doğal Sit Alanı, } \\
\text { Kentsel Sit Alanı }\end{array}$ & Çamlıhemşin & Kaplıca Köyü, Ayder Mevki \\
Kentsel Sit Alanı & Merkez & \\
Arkeolojik Sit & Merkez & Rize Kalesi Ve Çevresi \\
Doğal Sit & Çamlıhemşin & Fırtına ve Hola derelerinin Bulunduğu alan \\
Arkeolojik Sit & Çamlıhemşin & Zil Kale Köyü,Kale-i Bala ve Çevresi \\
Doğal Sit Alanı & Çamlıhemşin & Çat Köyü, Şeytanlı Mevkii \\
Tarihi Sit Alanı & Pazar & Şehitlik Köyü \\
(Ayder Yaylası & Çamlıhemşin & Merkez \\
Yukarı Ambarlık) & & \\
Tarihi Sit & Pazar & Şehitlik Köyü \\
\hline
\end{tabular}

Kaynak: Kültür ve Turizm Bakanlığı (2012)

İl içinde ayrıca cami, kilise, sivil mimari örneği, köprü, ağaç, kale, oluşan, ilgili Koruma Kurulları tarafından tescili yapılmış 169 adet eser yer 
almaktadır. Elde edilen veriler derlenerek Rize ili turizmiyle ilgili bilgiler 2012/2013/2014 yı1ları için aşağıdaki tabloda yer almıştır.

Tablo 4: Rize İline Gelen Turist Sayıları

\begin{tabular}{|c|c|c|}
\hline Yerli Turist Sayıs1 & \multirow{2}{*}{2012} & 524.021 Kişi \\
\hline Yabanc1 Turist Sayısı & & 61.675 Kişi \\
\hline Toplam & & 585.696 Kişi \\
\hline Yerli Turist Sayısı & \multirow{3}{*}{2013} & $560.000 \mathrm{Kişi}$ \\
\hline Yabancı Turist Sayısı & & 60.000 Kişi \\
\hline Toplam & & 620.000 Kişi \\
\hline Yerli Turist Sayısı & \multirow{3}{*}{2014} & $580.000 \mathrm{Kişi}$ \\
\hline Yabancı Turist Sayısı & & 70.000 Kişi \\
\hline Toplam & & $650.000 \mathrm{Kişi}$ \\
\hline
\end{tabular}

Kaynak:http://www.milliyet.com.tr/rize-yerelhaber-603420.(2015)ve

http://www.haberci53.com/rize/rizeye-gelen-yerli-ve-yabanci-turist-sayisih12926.html (2015).

Tabloda 2012, 2013 ve 2014 yıllarında Rize iline gelen yerli ve yabanc1 turist sayıları gösterilmiştir. Tabloda görüldüğü üzere yıllar itibarıyla Rize iline gelen yerli ve yabancı turist sayılarının artışı genel olarak değerlendirildiğinde konaklama yapan turist sayılarının artmasıyla ilde ve yaylalarda yer alan konaklama işletmelerinde de bir artış görülmektedir. Dolayısıyla Rize'de yapılan yayla turizmi faaliyetleri kapsamında gelen yerli ve yabancı konukların konaklama ihtiyaçlarını karşılamak üzere kurulan konaklama işletmelerinin gelirleri ile de Rize ilinin ekonomik anlamda bölgesel kalkınmasına katkı sağlanmaktadır. Bu doğrultuda yeni yatırımların yapılması istihdamı da olumlu etkileyecektir. Kalkınma doğrultusunda yatırımların yapılması ve bunun sonucunda ortaya çıkacak istihdam da etkin bir sonuçtur. Rize ilindeki konaklama ihtiyacını karşılayacak işletmeler ise aşağıdaki tabloda yer almaktadır.

Tablo 5. Rize İlinde Bulunan Turizm İşletme Belgeli Konaklama Tesisleri 


\section{İşletme Belgeli Konaklama Tesisleri}

\begin{tabular}{llll} 
Tesisin Adı & Sınıfı & Oda Sayısı & $\begin{array}{l}\text { Yatak } \\
\text { Sayısı }\end{array}$ \\
\hline Çavuşoğlu Otel & $* * *$ & 89 & 178 \\
Kaçkar Resort Otel & $* * *$ & 42 & 86 \\
Lazlakar Otel & $* * *$ & 25 & 50 \\
Patulya Otel & $* * *$ & 55 & 110 \\
Aydoğan Otel & $* *$ & 26 & 52 \\
Yalta Otel & $* *$ & 20 & 40 \\
Okutur Otel & $* *$ & 26 & 52 \\
Green Suada butik otel & Butik Otel & 60 & 120 \\
Zümrüdü Anka Konaklama & Özel Kon.Tesisi & 7 & 14 \\
Tesisi & & \\
\hline
\end{tabular}

Kaynak: http://www.rizekulturturizm.gov.tr/ (2015).

Tabloda Rize ilinde bulunan Turizm işletme belgeli konaklama tesisleri, sınıfı, oda ve yatak sayıları gösterilmiştir. Gelen yerli ve yabancı turistler mevcut konaklama tesislerinde konaklama yapabilmektedir. Turistlerin konaklama süreleri boyunca yeme-içme ihtiyaçlarının giderilmesinde yiyecek-içecek işletmeleri gibi gıda sektöründe yer alan işletmeler de önem kazanmakta, bu sayede işletmeler de kar elde edebilmektedir. Dolasıyla da Rize iline ekonomik olarak katkı sağlanmaktadır.

\section{SONUÇ}

Turizm sektörü sosyo-ekonomik olgu özelliğiyle birlikte çok hızlı bir gelişim göstermektedir. Gelişen turizm sektörü bir ülkenin ödemeler dengesinin düzelmesinde, gelir yaratılmasında dolayısıyla ülke döviz gelirinin arttırılmasında, bağlantılı olduğu diğer birçok sektörün hareketlenmesinin sağlanmasında (inşaat, yeme-içme, eğlence, taşımacıllk vb.) istihdam olanaklarının yaratılarak işsizlik probleminin yükünün azaltılmasında önemli etkilere sahiptir. Genel olarak turizm küçük ve orta boy işletmelerin gelişmesini desteklemektedir.

Doğu Karadeniz'in sahip olduğu yayla turizmi potansiyelinin oluşturulması kadar bu bölgelerle ilgili farkındalığın sağlanması ile koruma 
sağlanmalıdır. Yayla turizmi alanlarında turistlerin yararlanacağı donanımın oluşturulması alt ve üst yapıya ait yatırımları gerektirmektedir. Bu nedenle bölgesel konaklama alanları cazibe noktalarına yakın mevcut alt yapı olanaklarının olduğu noktalarda seçilmelidir. Bu noktalardan sonra yaylalara çıkan yollar mevcut durumuyla korunmalı, asfalt ve kolay ulaşabilir yollardan kaçınılmalıdır. Yaylalarda konaklama, alışveriş, yeme içme konularında öncelikle mevcut yapılardan faydalanılmalı, bu yapılardan özgün olanlarının aslına uygun restorasyonu ile turizme kazandırılmaları teşvik edilmelidir. Yapılaşmanın yoğun olduğu yaylalarda yapılaşma durdurulmalıdır.

Rize'de turistlerin ilgisini çekebilecek farklı güzelliklerde yaylalar bulunmaktadır. Gittikçe popülaritesi artan bölgenin yayla turizmine kazandırılması yapılan yatırımlarla gerçekleştirilmiştir. Bölgede sürdürülebilir turizm kapsamında yapılan faaliyetlerinin basın ve yayın yoluyla tanıtımının sağlanması gereken ilgiyi daha da artıracaktır. Turizm sektöründe faaliyet gösteren tüm kişi ve kuruluşların çevreci ve doğa dostu davranış ve tüketim alışkanlıklarının gelişmesi için özendirici çalışmalar yapılmalıdır. Gezi faaliyeti sırasında çevreye hiçbir şekilde atık bırakılmamalı ve doğada silinemeyecek izler bırakmamasına özen gösterilmelidir. 2634 sayılı Turizmi Teşvik Kanunu ve Türk turizminin geliştirilmesi kapsamında arazi tahsislerini gerçekleştirmek, turizm yatırımlarını teşvik etmek, planlı ve sürdürülebilir turizm politikası çerçevesinde mevcut kaynakları ülke ekonomisine aktarmak bölgesel kalkınmaya oldukça büyük katkı sağlamaktadır.

Turizm sektörü ile bölgesel kalkınmanın desteklenmesi mevcut potansiyelin değerlendirilmesiyle sağlanabilir. Bu yolla kalkınmanın anı sıra bu bölgelere olan farkındalı̆̆ın sağlanmasıyla da doğal rekreasyon alanlarının korunmasına da katkıda bulunulmuş olacaktır. Kalkınmanın yanı sıra potansiyel alanların korunması sağlanmış olacaktır.

Doğu Karadeniz de bulunan Rize ve yaylaları hızla turistik amaçlı bazı yatırımlar ile turistlerin ilgi odağı haline gelmektedirler. Bunlardan en çok tanınanlardan ve dolayısı ile tercih edilenlerden biri de Ayder yaylası olduğunu bilmekteyiz. Gittikçe popülaritesi artan bölgenin yayla turizmine kazandırılması yapılan yatırımlarla gerçekleştirilmiştir. Ayder yaylası 1987 
yılında bakanlar kurulu kararıla turizm bölgesi ilan edilmiştir. Belediye mücavir alanı içerisinde kalan bu bölgede gelişigüzel yapılaşma başlamıştır. Daha sonra 1994 yılında Milli park ve 1998 yılında doğal sit alanı ilan edilmiştir. 2006 yılında da Bakanlar Kurulu Kararı ile 'Kültür ve Turizm Koruma Gelişim Bölgesi' ilan edilmiştir. İki yıl içinde koruma amaçlı imar planı oluşturulması gerekirken bu güne dek gerçekleştirilememiştir.

Son bir karar ile Ayder yaylası olarak ifade etmiş olduğumuz bölgede yapılaşmanın çarpık etkisi nedeniyle bölgenin maruz kaldığı zarar ve tahrifatın önlenmesi doğal ortamın korunması amacıyla yapıların büyük bir kısmının kaldırılmasına belediye meclisi tarafından karar verilmiştir. Böylesi özelliklere sahip bölgeler hem turistik cazibe merkezi olarak hizmet vermeye ve çarpan etkisi ile çevredeki diğer sektörlere de katma değer yaratması amaçlanmaktadır. Ancak büyümenin getirdiği olumsuzlukların yaratacağı negatif etkilere de engel olunmaya çalışılmaktadır.

Bütün bunların yapılmasındaki ana amaç bu bölgenin sahip olduğu doğal güzellik, yürüyüş parkurları, trekking yapma olanakları ve kaplıca suları, bölgeye özgün ürünlere sahip mutfağı ile mevcut potansiyelin turistik getirisinden faydalanmak ve koruyarak sürdürülebilirliğini sağlamaktır.

Turizm sektörünün en yadsınamaz etkilerinden biri de diğer sektörlere olan çarpan etkisidir. Turizm faaliyetleri, turistik cazibe merkezi olan destinasyonlarda istihdamı artırmakta, inşaat ve gıda sektörlerinin canlanmasını sağlamaktadır. Fakat turizm ile ilgili faaliyetlerin yapılması esnasında her türlü üretim faktörünün bölgeden karşılanıyor olması gerekmektedir. Tedariklerin bölgeden temin edilmemesi halinde bölgesel kalkınmaya etkisi istenilen seviyede olmayabilir.

\section{KAYNAKLAR}

Albayrak, A. (2013). Alternatif Turizm, Detay Yayıncıllk, Ankara.

Atasoy, M. ve, BIYIK, C. (2005). Mera ve Yaylaların Zamansal Değişiminin Tespitinde Dijital Fotogrametriden Yararlanma, 15-16 Eylül Türkiye'de Arazi Toplulaştırması Sempozyumu, Mevlana Kültür Merkezi, Konya. s. 199-208. 
Bilginoğlu, A. (1995). “Kapadokya'nın Bölgesel Gelişmesinde Turizm Potansiyelinin Önemi, Bu Potansiyelden Yararlanılmasına Yönelik Olarak Uygulanmakta Olan Politikaların Değerlendirilmesi ve Öneriler". Kapadokya 'nın Turistik-Kültürel Potansiyeli ve Pazarlama Sorunları Hafta Sonu Semineri.

Bilici, N. (2014). "Yayla Turizminin Bölgesel Ekonomik Kalkınmadaki Rolü: Ayder Yaylası Örneği” International Conference In Prague, Czech Republic, s. 76.

Braden, P. V. and Louse, W. (1980). "Bringing Travel, Tourism and Culturel Resource Activities in Harmony With Regional Economic Development" Tourism Marketing and Management Issues, George Washington Üniversity, Washington.

Çelik Uğuz, S. (2011), "Sürdürülebilir Turizm Kapsamında Burhaniye'nin Alternatif Turizm Potansiyeli”, Marmara Coğrafya Dergisi Say1: 24, Temmuz - 2011, S. 332-353 İstanbul.

Çetiner, E. (1998) “Turizmde Bölgesel Kalkınma, Verimlilik ve Kaynakların Etkin Kullanımı” 1. Turizm Şurası, Turizm Bakanlığı, Ankara.

Daşc1, M. ve Çomaklı, B. (2006). Atatürk Üniversitesi. Ziraat Fakültesi Dergisi. 37 (2), 275-280.

Doğanay, H. (2001). Türkiye Turizm Coğrafyası. Çizgi Kitabevi, 3. Baskı, Konya.

Doğaner, S. (2001). Türkiye'nin Turizm Coğrafyası. İstanbul, Çantay Kitabevi Durgun, A. (2006). "Bölgesel Kalkınmada Turizmin Rolü: Isparta Örneği”, Süleyman Demirel Üniversitesi Sosyal Bilimler Enstitüsü, Isparta.

Ertürk, M. (1995). İskilip’te Yaylacılı̆̆ın Sosyal ve Ekonomik Hayata Etkileri, Atatürk Üniversitesi Sosyal Bilimler Enstitüsü, Erzurum.

Hacıoğlu, N. ve Avcıkurt, C. (2011). Turistik Ürün Çeşitlendirilmesi, Nobel Yayıncilik.

Ildırar, M. (2004). Bölgesel Kalkınma ve Gelişme Stratejileri, Nobel Yayın Dağıtım, Ankara, s.6. 
İTO, (1997). Karadeniz Bölgesinde Yayla Turizminin Geliştirilmesi, Bölgesel Gelişme ve Çevreye Uyumlu Yapılaşma, İstanbul Ticaret Odası, Yayın no: 1997-27.

İzgi, M. T. (2007). Osmaniye İlinin Turizm Potansiyelinin Bölgesel Kalkınma Politikaları Açısından Değerlendirilmesi Ve Sürdürülebilir Turizmin Gelişimi İçin Bir Model Önerisi. İstanbul Üniversitesi, Sosyal Bilimler Enstitüsü, Turizm İşletmeciliği Anabilim Dalı, Yayımlanmamış Yüksek Lisans Tezi, İstanbul.

Kilıçlar, A. (1998). Turizmin Bölgesel Ekonomik Etkileri ve Kemer Örneği. Gazi Üniversitesi Turizm İşletmeciliği Eğitimi Anabilim Dalı, Basılmamış Yüksek Lisans Tezi, Ankara.

Kim ,H., Chen, J. ve Shawn, J.(2006). “Tourism Expansion and Economic Development: The case of Taiwan”, Tourism Management, 27 (5): 925-933.

Mckinnon, R. (1964). "Foreign Exchange Constraint in Economic Development and Efficient Aid Allocation", Economic Journal, 74: 388-409.

Ögel, B. (2000). Türk Kültür Tarihine Giriş, T.C. Kültür Bak. Yayımlar Dairesi Başkanlığı Kültür Eserleri Dizisi 46, 4. Baskı, C.9, Ankara.

Robert, W., Mc Intosh, C.R.Goeldner (1990). “Tourism Principles,Practices”. Süleyman Demirel Üniversitesi Vizyoner Dergisi Y.2011, C.3, S.5. s.54-71

Uçkun, S. (2004). "İ̧letme ve İ̧sletme Türleri”, Turizm İşletmeleri, Editörler; Şehnaz Demirkol, Burhanettin Zengin, Değişim yayınları, İstanbul.

Yıldız, Z. (2011). "Turizmin Sektörünün Gelişimi Ve İstihdam Üzerindeki Etkisi”.

http://tr.wikipedia.org/wiki/Rize Erişim tarihi: 20.05.2017.

http://www.milliyet.com.tr/rize-yi-650-bir-turist-ziyaret-etti-rizeyerelhaber-603420/ Erişim tarihi: 20.05.2017.

http://www.haberci53.com/rize/rizeye-gelen-yerli-ve-yabanci-turistsayisi-h12926.html Erişim tarihi: 20.05.2017. 
http://www.rizekulturturizm.gov.tr/TR,113345/isletme-belgelikonaklama-tesisleri.html Erişim tarihi: 20.05.2017. http://rizesube.ormansu.gov.tr/Rize/Libraries/orkoy/R\%C4\%B0ZE_D O\%C4\%9EA_TUR\%C4\%B0ZM\%C4\%B0_MASTER_PLAN_ TASLA\%C4\%9EI.sflb.ashx Erişim Tarihi: 09.07.2017. 